\title{
Visibles pero diferentes: la mujer en la obra documental agraria de José Neches $^{1}$
}

\author{
Ana Melendo Cruz ${ }^{2}$
}

Recibido: 9 de octubre de 2017 / Aceptado: 3 de agosto de 2018

Resumen. La aproximación a la obra documental de José Neches, producida en su mayoría por el Ministerio de Agricultura, resulta decisiva en la comprensión del documental rural en España porque nos permite adentrarnos en el estudio de las comunidades campesinas durante la época franquista. El presente trabajo quiere ocuparse de identificar en su cine las marcas de un pasado con el que componer la memoria de la colectividad atendiendo, principalmente, al papel desempeñado por la mujer en el seno de estas sociedades agrarias.

Palabras clave: Cine; documental agrario; mujer; José Neches; SEA.

\section{[en] Visible but different: the woman in the agrarian documentary work of José Neches}

\begin{abstract}
The approach to the documentary work of José Neches, produced for the most part by the Ministry of Agriculture, turns out to be decisive in the understanding of rural documentary in Spain because it allows us to penetrate in the study of the peasant communities during the Franco regime. This research aims to identify in Neches' cinema the marks of a past with which to compose the collective memory looking, particularly, to the role carried by the woman in the core of these peasant societies.
\end{abstract}

Keywords: Cinema; agrarian documentary; woman; José Neches; SEA.

Sumario. 1. Introducción. 2. Algunos apuntes sobre José Neches. 3. Un poco de historia. 4. Entre la invisibilidad y la diferencia. 4.1 Las películas de José Neches en el SEA. 5. A modo de conclusión.

Cómo citar: Melendo Cruz, A. (2018) Visibles pero diferentes: la mujer en la obra documental agraria de José Neches, en Anales de Historia del Arte nº 28 (2018), 315-338.

\section{Introducción}

Cualquier producción cinematográfica puede definirse como un producto cultural y artístico que, siendo una manifestación de la sociedad que la produce,

1 Este trabajo ha sido realizado en el marco del proyecto de investigación La contribución de José Neches al documental agrario español del franquismo (1945-1976) del Programa Estatal de Fomento de la Investigación Científica y Técnica de Excelencia del Ministerio de Economía y Competitividad (referencia HAR201677137-P). Convocatoria 2016. Investigadores principales: Ana Melendo Cruz y Pedro Poyato Sánchez.

2 Universidad de Córdoba. Departamento de Historia del Arte, Arqueología y Música aa1mecra@uco.es Código ORCID: 0000-0001-8985-6830 
se convierte en un reflejo de la comunidad en la que se inscribe. Aunque es cierto que la mirada cinematográfica no es capaz de constituirse, en ningún caso, en relato objetivo de los acontecimientos históricos, también es verdad que los mensajes proyectados a través del cine son ecos de las sociedades en las que se desarrollan y, lo que es más importante, ayudan a componer la memoria de la colectividad. Y es que, como asegura Cristóbal Gómez Benito, "la historia visual busca aportar la reflexión al conocimiento y a la difusión de los vínculos entre imágenes e historia, y en especial, al modo en que la imagen cinematográfica se erige en escritura complementaria de la que desarrollan las diversas corrientes historiográficas" 3 . Pero, esa recuperación de la memoria histórica que ha despertado en nuestro país un gran interés desde hace algún tiempo, exige, por lo general, de la puesta en valor de un patrimonio cultural que permita completar muchas de las lagunas aún existentes. José Colmeiro explica que, "este despertar ha sido el resultado de los movimientos políticos, judiciales y sociales que reclaman que se desentierre, literal y simbólicamente, el pasado (las atrocidades y violaciones de los derechos humanos cometidos durante la Guerra Civil y posteriormente)"4. En los últimos años la revisión del pasado ha absorbido a estudiosos de múltiples disciplinas, y todo ello porque, tal y como se señala en el Plan de Estrategia Española de Ciencia y Tecnología $y$ de Innovación 2016-2020, la historia y los recursos, las culturas locales y el patrimonio poseen un valor esencial en la construcción de las identidades y los valores comunes 5 . Por eso, la labor desempeñada, desde hace algunos años, por el Departamento del Servicio de Publicaciones, desde el área de Archivos, Biblioteca y Mediateca del Ministerio de Agricultura y Pesca, Alimentación y Medio Ambiente en torno a la recuperación, restauración y distribución de sus fondos cinematográficos se hace fundamental a la hora de conocer y estudiar muchas de las aportaciones más interesantes, realizadas en nuestro país, sobre el documental rural español; investigaciones previas, referidas a la obra de otros documentalistas agrarios, como el marqués de Villa Alcázar o Pascual Carrión entre otros, así lo han demostrado ${ }^{6}$.

Entonces, en esa reconstrucción del pasado a través de la imagen cinematográfica, que nunca resulta fácil por los discursos dispares que de ella se desprenden, es posible leer las marcas de un ayer, ni siquiera lejano, que nos permiten conocer e identificar las diferencias, sobre todo teniendo en cuenta que los fondos documentales en los que se centra nuestro estudio están producidos por organismos oficiales, gubernativos o dependientes de ellos, existentes en el franquismo. Esta reflexión resulta de especial interés por cuanto

3 Gómez Benito, J. (2015). "La mujer en la agricultura tradicional. Una mirada desde la historia y la sociología visual". En Ortega López, Ma T. (Ed.). Jornaleras, campesinas y agricultoras. La historia agraria desde una perspectiva de género. Zaragoza: Monografías de Historia Rural, 11. SEHA, 210-211.

4 Colmeiro, J. (2011). “¿Una nación de fantasmas?: Apariciones, memoria histórica y olvido en la España postfranquista", en $452^{\circ} \mathrm{F}$. \#04, 29.

5 Plan de Estrategia Española de Ciencia y Tecnología y de Innovación 2016-2020. Obtenido de: http: //www.idi. mineco.gob.es/stfls/MICINN/Investigacion/FICHEROS/Estrategia_espanola_ciencia_tecnologia_Innovacion. pdf [Consulta: 23 de enero de 2017].

6 Véanse: Gómez Tarín, F. J., y Parejo, N. (Coords.) (2013). Discursos y narraciones en el documental rural: el marqués de Villa-Alcázar. La Laguna (Tenerife): CAL, Cuadernos Artesanos de La Latina, XX; Ortega Arjonilla, E. (Ed.) (2017). De cultura visual y documentales en España (1934-1966): la obra cinematográfica del marqués de Villa Alcázar. Granada: Editorial Comares. 
nuestra investigación pretende aproximarse al estudio de la mujer y el papel que esta desempeña en las comunidades agrarias de la España franquista, a partir de la obra documental, recientemente restaurada y digitalizada, de José Neches Nicolás, quien, entre 1945 y 1976, realiza cuarenta y siete documentales producidos por, el entonces, Ministerio de Agricultura. Efectivamente, partiendo de la hipótesis de que en estos documentales sobresalen las marcas de un tejido ideológico y que se dan en ellos unas características plásticas cuyo estudio supone un paso más en la reconstrucción de la historia del documental en nuestro país, la finalidad principal de este trabajo se plantea en base al estudio de esas huellas referidas, fundamentalmente, a la construcción que de la imagen de la mujer tiene lugar en la obra de este cineasta y de los elementos estéticos, es decir, de la forma de hacer de José Neches. Este fin, que marca la directriz principal de nuestro estudio, nos permite establecer algunos objetivos relacionados con la identificación de los estereotipos sociales que se dan cita a lo largo de las distintas etapas de la dictadura, de manera que podamos llegar a comprender, a través de las imágenes de Neches, gran parte de los cambios sociales, políticos y económicos, protagonizados por la mujer, en la sociedad española de aquellos años.

Teniendo en cuenta los objetivos citados, en nuestro acercamiento al objeto de estudio partimos de la consideración del cine como un medio de representación implicado, tal y como asegura $\mathrm{Hearth}^{7}$, en la construcción de significados sociales y culturales. De esta forma, se hace necesario abordar nuestro trabajo desde un modelo que se caracteriza por la interdisciplinariedad y el diálogo entre los distintos medios de conocimiento, atendiendo así a lo que Casetti denomina teorías de campo, ya que como dice el autor, "este tipo de investigación nace de la existencia de un problema revelador de las preocupaciones del teórico y de los síntomas del objeto teorizado"

Se trata, por tanto, de resolver diversos problemas, provenientes de sectores disciplinares diversos, que atañen, de igual modo, al sujeto, a la representación o la construcción de la identidad. Abordaremos así, en lo que sigue, un análisis fílmico en torno a la significación del papel de la mujer en las películas de Neches ahondando en la relación entre texto y contexto, que deberá partir necesariamente de un acercamiento interdisciplinar al objeto de estudio en cuanto a la representación de lo femenino en el cine y en su significación cultural e histórica.

Es evidente que nuestro trabajo no quiere ocuparse de narrativas que desde el presente evocan el pasado, ya que sus autores no vivieron los acontecimientos descritos, sino de otras que nacen en el pasado y que van a ser revisadas desde el presente. Se trata por tanto de la interpretación temporal de unos valores que forman parte de la vida de una sociedad, pero siempre teniendo en cuenta que, como asegura Eco, "un texto, tal como aparece en su superficie (o manifestación) lingüística, representa una cadena de artificios expresivos que el destinatario debe actualizar". Parece inevitable entonces que, en esa revisión, el destinatario del que habla Eco, se enfrente a los textos del pasado con sus propias normas

\footnotetext{
Heath, S. (1981). Questions of Cinema. Bloomington: Indiana University Press.

Casetti, F. (2000). Teorías del cine. Madrid: Cátedra, 201.

Eco, U. (1987), Lector in Fabula. Madrid: Lumen, 1987, 73.
} 
y valores, Jauss lo llama horizonte de expectativas ${ }^{10}$, convirtiéndose así, como señala Iser, en:

(...) un potencial de efectos, que solo es posible actualizar en el proceso de lectura (...) Pues la obra es más que el texto, puesto que solo cobra su vida en la concreción y, por su parte, esta no se halla totalmente libre de las aptitudes que introduce el lector, aun cuando tales aptitudes sean activadas según los condicionantes del texto ${ }^{11}$.

\section{Gómez Benito asegura que:}

La historia se ha basado en la primacía de lo escrito. Y tiene que afrontar el hecho de la utilización de ese testimonio de lo "visto" que es la imagen. En las manos del historiador, la imagen fotográfica [o cinematográfica en este caso] puede tener varios usos. Los dos principales tienen que ver con dos usos fundamentales de la historia: el registro de lo que ha sucedido y la narración de lo sucedido. La distinción no es tan clara como parece. Pero también hay otro uso de la fotografía por el historiador: la de convertirla en auxiliar de la memoria (...) En este sentido, la fotografía se convierte en una herramienta de la indagación histórica reciente, como complemento de las fuentes orales ${ }^{12}$.

Por eso se hace necesario atender en lo que sigue, a partir del análisis cinematográfico de los documentales seleccionados, a una escritura, en la que cobra especial relevancia el contexto en el que fue concebida, con la intención última de completar y actualizar el sentido que emana de unos vestigios que se convierten en instrumentos para comprender por un lado, el destino histórico de una época, y por otro, el legado artístico de su creador.

\section{Algunos apuntes sobre José Neches}

José Neches nace en Zamora en 1911 y muere en Madrid en 1994. Emparentado desde la cuna con la agricultura y la ganadería por los negocios familiares, iniciados por su abuelo y continuados por su padre, decide estudiar la carrera de Ingeniero Agrónomo. Una vez finalizada, en 1941, y obtener, complementariamente a sus estudios de agronomía, el título de: Técnico en Cinematografía. Director Realizador con Carnet Sindical, ocupa un puesto de Ingeniero Agrónomo en el Sindicato Nacional del Olivo, y más tarde es destinado a Guinea como funcionario del Ministerio de Agricultura. Después de dos años vuelve a España para desempeñar un puesto en la Jefatura Agronómica de Orense y en 1947 es designado a la Jefatura Agronómica de Zamora, donde permanece, hasta que solicita una estancia en Estados Unidos (Cali-

10 Jauss, H. R. (1986), Experiencia estética y hermenéutica literaria: Ensayos en el campo de la experiencia estética. Madrid, Taurus.

11 Iser, W. (1987). El acto de leer. Madrid: Taurus, 11-44.

12 Gómez Benito, J. (2015). "La mujer en la agricultura tradicional. Una mirada desde la historia y la sociología visual", op. cit., 312 . 
fornia), participando en un programa de cooperación internacional hasta su vuelta a España y su definitiva reincorporación al Ministerio de Agricultura, lugar en el que continúa adscrito desde 1972 al Cuerpo Nacional de Ingenieros Agrónomos, en la Dirección General de Capacitación y Extensión Agrarias hasta su jubilación en 1981, desarrollando su actividad en la dirección y realización de películas y documentales.

La llegada de José Neches al Servicio de Extensión Agraria (en adelante SEA) se produce en 1959, después de que se le concede el reingreso al Ministerio de Agricultura en el Organismo Autonómico de Extensión Agraria como Técnico en Cinematografía. Es cierto que su carrera como cineasta comienza unos años antes, siempre bajo la supervisión del Ministerio de Agricultura, concretamente en 1945 con la película Cortijo andaluz, y a partir de entonces realiza, ininterrumpidamente, más de cuarenta películas documentales, relacionadas con el mundo rural, para el Ministerio de Agricultura y otros Organismos. En todo caso, su amor por el cine y el espectáculo no hemos de verlo solamente ligado al documental rural. Por el contrario, durante mucho tiempo se mantiene unido al mundo del espectáculo a través de su afición al flamenco y como empresario de espectáculos y salas de cine, gestionando varios de estos locales en la Gran Vía Madrileña. También realiza alguna incursión como director en el cine de ficción a partir de su estancia en Guinea con la intención de mostrar a la sociedad cómo era la vida en una de las últimas colonias españolas. De ahí surge el título Afan Evu (1945) que es una adaptación de la obra de 1943 de Wenceslao Fernández Flores: El bosque maldito $^{13}$.

No obstante, en su interés por promover, como se verá más adelante, la docencia a través del cine, forma, en todas las regiones españolas, a un grupo de Agentes de Extensión Agraria que se especializan en la realización de cine, sobre todo de cine documental. Pero no debemos olvidar que los organismos institucionales en los que desempeña su tarea como cineasta y docente están controlados por un estado fascista que vigila muy de cerca cada uno de los movimientos de aquellos que, bajo el paraguas de ciertas acciones educativas que se llevan a cabo durante los cuarenta años de dictadura, intentan liberar del atraso y la miseria cultural, humana y profesional a los habitantes del mundo rural. Precisamente el SEA, institución en la que el cineasta lleva a cabo su labor más fructífera, nace con la intención de ayudar a los agricultores en el progreso de un mundo cambiante, el agrícola, incorporando, de una manera afectiva, a las familias, los jóvenes y, en definitiva, a las comunidades rurales, a las tereas de desarrollo. En este sentido cobra un protagonismo fundamental el cine puesto que, tal y como afirma Gerardo García Fernández:

"Este objetivo genérico se concreta específicamente en la educación para el desarrollo. En este modelo se entiende que educar es adiestrar a los agricultores en cómo plantear los problemas, cómo analizar las formas de resolver y cómo abordar las acciones correspondientes (...) La labor educativa requiere utilizar métodos y técnicas de promoción de acciones y de animación social"14.

13 Para obtener más información al respecto consultar: José Neches Nicolás (2017). Madrid: Ministerio de Agricultura, Alimentación y Medio Ambiente, 11-13. Se puede consultar el opúsculo accesible online: (https: // www.mapama.gob.es/es/ministerio/archivos-bibliotecas-mediateca/mediateca/biofilmografia-neches_tcm30379746.pdf.

14 García Fernández, G. (2009). “La extensión educativa ¿Una necesidad vigente?”. En Rodríguez, A., García Gutiérrez, J., y García Fernández, G. (Eds.). El Servicio de Extensión Agraria. Madrid: Ministerio de Medio Ambiente y Medio Rural y Marino, 238-239. 
Se trata de que el agricultor se encuentre respaldado, tal y como explica Juan Manuel García Bartolomé, "por la solvencia técnica de un organismo que trabaja permanentemente a su lado. La consideración de los agricultores no solo como beneficiarios fundamentales del desarrollo, sino como agentes de la creación y evolución del mismo (...) Desde una perspectiva actual, puede afirmarse que el SEA fue un organismo movilizador de recursos y voluntades para promover el progreso agrario y el desarrollo de las comunidades rurales, que aplicó enfoques teóricos y metodológicos que resultaron innovadores en las políticas públicas"15.

Las acertadas palabras de García Bartolomé nos permiten reconducir este estudio hasta la aproximación de un cine documental agrario que ha forjado, como veremos, una representación muy nítida acerca del papel desempeñado por la mujer en una sociedad basada en arcaicos modelos patriarcales y unos principios de doctrina y moral católica que acabaron enraizándose e imponiéndose en todos los ámbitos de la sociedad española, tanto en el ámbito público como en el ámbito privado. Por eso, nos parece necesario realizar una visión panorámica, aunque un tanto fugaz, del contexto político, social y económico en el que estas mujeres se desenvuelven.

\section{Un poco de historia}

La producción cinematográfica de José Neches comienza en pleno periodo autárquico, unos años, estos primeros de la dictadura, caracterizados por la gran empresa emprendida por el Nuevo Régimen en aras de una regeneración total, de una nación nueva forjada en su lucha contra el $\mathrm{mal}^{16}$. Se pretende reconstruir la patria a partir de la disolución de unos ideales provenientes del periodo republicano, que atacan las esencias tradicionales sobre las que se sustentan los presupuestos políticos del nuevo periodo dictatorial. Así lo expresa el Profesor Julián Casanova:

En realidad, ese objetivo de redimir a España era el común denominador de las fuerzas políticas y sociales que se sumaron a esa "gran empresa", identificada más por lo que querían destruir -la República, el liberalismo, el comunismo-que por un acuerdo sobre la definición del nuevo régimen ${ }^{17}$.

Sin duda, una de las consecuencias inmediatas de la restauración del Nuevo Régimen fue la sistemática represión de las mujeres y, por consiguiente, la abolición de los derechos igualitarios y de ciudadanía que se habían logrado en el régimen democrático de la Segunda República.

Escribe la profesora Mary Nash en su ensayo Vencidas, represaliadas y resistentes que, "el régimen franquista se fundó en un rígido sistema de género que marcó

15 García Bartolomé, J. M. (2009). “Prólogo”. En Rodríguez, A., García Gutiérrez, J., García Fernández, G. (Eds.). El servicio de Extensión Agraria. Vivencias, recuerdos y vigencias. Madrid: Ministerio del Medio Ambiente y Medio Rural y Marino, 9.

16 Casanova, J. (2015). "La dictadura que salió de la guerra". En Casanova, J. (Ed.). 40 años con Franco. Barcelona: Crítica, 54.

17 Ibidem. 45. 
la subalternidad de las mujeres mediante un nuevo orden jurídico que sostenía una jerarquía de privilegio masculino ${ }^{18}$.

Es así cómo el franquismo, sujeto a modelos reaccionarios con un fuerte componente religioso, encuentra en el sometimiento de la mujer uno de sus pilares más sólidos a la hora de establecer su política ideológica, económica y social ${ }^{19}$. Estos dispositivos, eficazmente actualizados, provocan una serie de diferencias sistemáticas y estructurales entre mujeres y hombres que se extienden, incluso, a épocas muy posteriores. Las consecuencias de la privación de derechos y libertades para las mujeres trajo consigo unos resultados tan negativos y devastadores que, tal y como afirma Ángeles Liñán "prácticamente todas las mejoras experimentadas durante la $2^{\mathrm{a}}$ República española en el terreno jurídico, social, educativo, político y en materia de igualdad entre hombres y mujeres quedaron sin efecto" 20 .

Precisamente, esa subordinación de la que habla Nash se cimenta en la distinción educativa entre hombres y mujeres apoyada en la Ley de Enseñanza Primaria de 1945 que permanece en vigor hasta 1970. En ella se determinan los principios de separación de sexos y feminización de la enseñanza.

Por todo ello, nos encontramos en unos años en los que las mujeres han sido privadas de derechos políticos y civiles, y la legislación favorece que las jóvenes abandonen regularmente sus estudios y cualquier tipo de actividad remunerada o relacionada con el ámbito público en aras de su permanencia en el ámbito doméstico bajo la protección de la figura paterna o conyugal.

La formación de la mujer, por tanto, adquiere un cariz cuyo objetivo, como resalta $\mathrm{M}^{\mathrm{a}}$ Teresa Gallardo Méndez en su libro Mujer, falange y franquismo, "era el de formar a la mujer para que su reclusión en la casa resultara eficaz y provechosa. Capacitarla para infundir valor al marido, disciplina a los hijos, para lo rezos, e incluso para practicar gimnasia sueca en el camino de la cocina al dormitorio" ${ }^{21}$.

Otras autoras como Ángeles Liñán García se refieren así a este hecho:

Igualmente, en el ámbito laboral, en 1942 se estableció la obligatoriedad de abandonar el trabajo en el supuesto de que se contrajera matrimonio. Y, una vez casadas, las mujeres tan solo podían acceder a un trabajo fuera del hogar familiar si contaban con la autorización marital y el marido no contaba con unos ingresos mínimos con los que mantener a la familia ${ }^{22}$.

En este sentido, creemos de obligado cumplimiento referirnos al imprescindible papel que juega la Sección Femenina en los hogares rurales tanto en el período autárquico como en la llamada etapa desarrollista porque, como indica José Manuel Díez Fuentes, dicha organización:

18 Nash, M. (2015). "Vencidas, represaliadas y resistentes". En Casanova, J. (Ed.). 40 años con Franco. Barcelona: Crítica, 191.

19 Para obtener unos datos más precisos del contexto histórico, político y económico durante la dictadura franquista, se puede consultar: (Payne, 1987), (Payne, 1997), (Tussel, 1996), (Riquer, 2010).

20 Liñan García, Á. (2016). La evolución del estatuto jurídico de las mujeres en España en materia de familia, matrimonio y relaciones paternofiliales. Arenal, 23 (2), 357.

21 Gallardo Méndez, Ma T. (1983). Mujer, falange y franquismo. Madrid: Taurus, 78.

22 Liñan García, Á. op. cit., 357. 
Recibe el "encargo" oficial de "movilizar" y "formar" política y socialmente a todas las mujeres españolas, en todas sus edades - niña, joven y adulta- y campos de actuación -trabajo, cultura, deportes, educación,...- como "misión” exclusiva; de esta forma se convierte en la única organización oficial femenina del Régimen ${ }^{23}$.

La reproducción de las palabras de Pilar Primo de Rivera dirigiéndose a los primeros Consejos Provinciales de las Secciones Femeninas de toda España arrojan luz, como vemos, sobre el objetivo de esta institución:

Os tenéis que dar cuenta de lo importante que es vuestra misión; los pueblos son las ruedas que mueven el carro de la organización, porque por muchos proyectos que hagamos en la Nacional y por mucha fe que tengamos arriba, si los pueblos no funcionan, no habremos conseguido absolutamente nada. Cada una tenéis en vuestro pueblo la base de nuestra organización, que es la familia, la parroquia donde aprendéis el Evangelio, el Municipio y el Sindicato, y alrededor de esto se tiene que desenvolver la vida de la Falange. Tenéis vosotras en vuestras manos la mejor parte de España: la gente campesina (...) Queremos que se encariñen con la tierra que es suya, con la casa que es suya y que será de sus hijos, con el ambiente limpio y despejado del campo ${ }^{24}$.

Efectivamente, las mujeres rurales encuentran en el seno del hogar la razón de su existencia, y en la familia la célula principal y unificadora de una estructura que, en el mundo rural, tal y como afirma Teresa María Ortega López:

Es entendida como institución globalizadora, como unidad de producción y consumo, convivencia, mutua ayuda y sociabilización (...) Una familia cuya organización y funcionamiento interno atiende a una sustancial asimetría estructurada en torno al género y la edad, que se perpetúa mediante el reforzamiento de la autoridad patriarcal ${ }^{25}$.

Aún así, en esa sociedad patriarcal impuesta, con matices en puntos muy concretos de la geografía española ${ }^{26}$, son muchas las mujeres que encabezan sus hogares,

23 Díez fuentes, J. M. (1995). República y primer franquismo: la mujer española entre el esplendor y la miseria, 1930-1950. Alternativas. Cuadernos de Trabajo Social, 3, 35.

24 Otero, L. (2004), La Sección Femenina. Madrid: Edaf, 196.

25 Ortega López, T. Mª (2015). "Introducción”. En Ortega López, T. Mª (Ed.) (2015). Jornaleras, campesinas y agricultoras. La historia agraria desde una perspectiva de género. Zaragoza: Monografías de Historia Rural, 11. SEHA, 16.

26 Según Ana Cabana y Elena Freire la sociedad gallega de la época "se presenta como referente de un supuesto matriarcado que precedería al ejercicio del poder político y económico androcéntrico. En esta corriente se insertaba, sin mayor dificultad, la existencia en Galicia de una excepcionalidad cultural, muy lejos de la duplicidad honra/vergüenza del sur de Europa, que representaba a las mujeres rurales como símbolos de independencia y que atrajo a varios antropólogos que realizaron importantes etnografías enfocadas al estudio de género en diferentes localidades de Galicia, mayoritariamente en las zonas costeras, ya desde los años ochenta del siglo XX. Cabana, A., y Freire, E. (2015). "Vendedoras de barro. Mujeres rurales y los límites de lo doméstico a mediados del siglo XX”. En Ortega López, T. Ma (Ed.) (2015). Jornaleras, campesinas y agricultoras. La historia agraria desde una perspectiva de género. Zaragoza: Monografías de Historia Rural 11. SEHA, 284-285. 
de tal forma que se ven obligadas a desarrollar trabajos irregulares para alimentar a sus familias. De este modo, las amas de casa hacen compatible el trabajo doméstico con otros, que en el ámbito rural están ligados, fundamentalmente, al campo y a las Granjas Escuelas ${ }^{27}$. José Antonio Pérez señala que, "Lejos de proteger el trabajo femenino, la legislación franquista expulsó a las mujeres del mercado de trabajo regular y las relegó a las actividades domésticas o al empleo sumergido, vinculado de un modo u otro a estas últimas"28.

A pesar de que España en los años cincuenta sigue apoyándose, fundamentalmente, en la agricultura, en 1951 se percibe un ligero cambio motivado por la apertura de la política económica del país y por la participación de este en diferentes organismos internacionales. No obstante la población continua siendo principalmente rural, por mucho que se comenzaran a producir ciertos cambios en la sociedad agraria protagonizados, sobre todo, por los efectos del éxodo rural, una lenta recuperación demográfica y el incipiente desarrollo económico con la expansión de los sectores secundario y terciario, hechos que provocan una crisis de la agricultura tradicional y, con ella, de la sociedad rural tradicional ${ }^{29}$.

Es cierto que el reclamo de una parte importante del sector femenino por el reconocimiento de sus derechos trae consigo algunas transformaciones en la legislación vigente. Por ello, como analiza Liñán García:

Se efectuaron varias reformas en el Código civil. La primera con la Ley de 24 de abril de 1958, inspirada en el principio de que, tanto en un orden natural como en el orden social, el sexo por sí solo no puede determinar en el campo del Derecho civil una diferencia de trato que implique, de algún modo, la limitación jurídica de la capacidad de las mujeres y el control de su cuerpo y actitudes. En el mismo sentido, declaraba que la familia no debe ser fuente de desigualdades, aunque sí instituir "ciertas diferencias orgánicas" derivadas de las funciones que en ella se atribuyen a sus componentes ${ }^{30}$.

Sin embargo, y teniendo en cuenta que la mujer sigue siendo víctima de la subordinación paternal y marital, que si decide abandonar el hogar queda privada de todo recurso económico y de la custodia de sus hijos, las mujeres siguen experimentando una vida de renuncias y de largas jornadas laborales, mal remuneradas en el mejor de los casos, que se prolonga hasta décadas muy posteriores. Aunque la Ley de Derechos Políticos, Profesionales y Laborales de la Mujer de julio de 1961 reconoce a la mujer los mismos derechos que al hombre en el ámbito público y privado, la discriminación laboral, en el sentido más amplio de la palabra, sigue siendo el principal problema de las, cada vez más, mujeres trabajadoras fuera de del hogar. Tanto es así

27 Aunque en 1940 en el sector agrícola los hombres constituían el 94,5\% estos datos no significaban que la mujer no realizase trabajos agrícolas, ya que cada 100 mujeres que trabajaban en el campo, 70 lo hacían en concepto de ayuda familiar, sin cobrar salario alguno, por lo que no figuraban en ningún tipo de censo. Obtenido de $L a$ mujer durante el franquismo. http: //www.vallenajerilla.com/berceo/garciacarcel/lamujerduranteelfranquismo. htm\#EDUCACIONGENERO. [ Consulta el 3/1/2017]

28 Pérez, J. A. (2004). Los espejos de la memoria. Historia oral de las mujeres de Basauri, 1937-2003. Basauri: Ayuntamiento de Basauri, 2004, 127.

29 Gómez, B., y LUQUE, E. (2015). Imágenes de un mundo rural. Madrid: Ministerio de Agricultura, Pesca y Alimentación, 30.

30 Liñán García, Á. (2016)., op. cit., 358. 
que desde dentro de la Sección Femenina se oyen voces en contra de la desigualdad laboral entre hombres y mujeres. Por eso, Carmen Salinas, asesora jurídica de la delegación nacional de la Sección Femenina, manifiesta lo siguiente en 1963 en la Revista de Trabajo:

Nos encontramos con que la mayoría de las reglamentaciones laborales que se van dictando establecen un discriminación básica entre el trabajo de hombres y de mujeres, pero no en el sentido de marcar para la mujer unos trabajos más adecuados a sus naturaleza y constitución, sino discriminado un salario inferior en una misma jornada de trabajo y en una misma actividad, estableciendo la excedencia forzosa por razón de matrimonio en muchas reglamentaciones, etc ${ }^{31}$.

Los años sesenta, por tanto, se manifiestan herederos de todo lo acaecido con anterioridad. Habría que esperar hasta 1973 para que la mujer tuviera una representación de cuatro miembros en el Congreso, y hasta 1975 para que la muerte del dictador significara una revisión profunda de la legislación vigente y la lucha enérgica de las mujeres por sus derechos. Sin embargo, aunque existe una generación joven que aspira a grandes cambios sociales y el movimiento de mujeres tiene gran repercusión en las diferentes instituciones los, tan esperados, cambios se demoran considerablemente a casusa de que la difusión de los viejos clichés, propuestos por el franquismo, tardan en desaparecer, como veremos a continuación, debido a que esos valores tradicionales de antaño se habían infiltrado con fuerza en la médula de la sociedad española.

\section{Entre la invisibilidad y la diferencia}

Aunque sin intención explícita de que así sea, los documentales agrarios anteriores y coetáneos a la obra fílmica de José Neches están plagados de presencias femeninas. Solo hay que echar un vistazo a las películas de temática rural contenidas en el Archivo NO-DO, o a otras de las que se encuentran en el fondo fotográfico y cinematográfico del Ministerio de Agricultura y pesca, Alimentación y Medio Ambiente (MAPAMA), como la, ya citada en este estudio, obra cinematográfica del marqués de Villa Alcázar, para darnos cuenta de que, aún encontrándose en escena, no existe el propósito ni la determinación de convertirlas en protagonistas o actantes de la imagen de un mundo, el rural, que, difícilmente, habría subsistido sin ellas. La consecuencia más inmediata de este hecho se traduce en una invisibilidad basada en el silencio, la transparencia y la subordinación a los cánones de una sociedad patriarcal creada por hombres, y en una forma de estar en el mundo que no solo afecta a su vida pública y privada, sino a la manera en que se escribe la historia de estas abnegadas mujeres $^{32}$. Y es que, tal y como señala Mary Nash:

31 Recogido en Nash, M. (2015). op. cit., 213.

32 Este ensayo pretende profundizar en el papel que se le otorga a la mujer en los documentales agrarios creados desde el Ministerio de Agricultura durante la dictadura franquista. Supone así una continuidad con respecto a algunos otros realizados con anterioridad. Véanse: Melendo, A. (2013). "Catequesis y vitaminas a pie de barbecho: la mujer en las primeras charlas cinematográficas del marqués de Villa Alcázar”. En Gómez Tarín, F. J., y Parejo, N. (Coords.). Discursos y narraciones en el documental rural: el marqués de Villa-Alcázar (pp. 73-93). 
Parece imposible percibir la experiencia histórica de las mujeres si se emplean los enfoques tradicionalmente utilizados por los historiadores, ya que, a nuestro entender, la "invisibilidad" de la mujer en la historia deriva precisamente de la definición misma que se ha dado a la historia (...) Si el prejuicio masculino ha condicionado la historiografía tanto tradicional como renovadora, la historia de la mujer se impone como estudio de aquellos campos hasta ahora poco estudiados y, por lo tanto, invisibles. Así, el contenido de la historia cambia en cuanto buscamos a la mujer como agente histórico y nos acerca a estas esferas y dominios donde hay mayor evidencia y participación de la mujer (...) Queda clara la necesidad de una revisión del bagaje metodológico habitual, así como de una ampliación de los campos de investigación histórica para abarcar estas áreas para poder detectar la mayor incidencia de las mujeres ${ }^{33}$.

Desde este enfoque planteado por Nash, el abordaje de la obra cinematográfica de Neches nos permite cuestionar la visión tradicional de la mujer en la sociedad y poner en tela de juicio algunos de los presupuestos básicos de la historiografía tradicional, porque, como sigue argumentando esta autora refiriéndose a la labor de las nuevas historiadoras:

\begin{abstract}
Al rechazar la imagen estereotipada predominante de la mujer, basada en la doble atribución de pasividad y bondad, o malignidad y poder, no intentan captar los mecanismos del dominio patriarcal. Tal postura les lleva a prever la necesidad de una reinterpretación de las fuentes y tesis tradicionales, junto con una tarea de elaboración de nuevas categorías de análisis histórico ${ }^{34}$.
\end{abstract}

En este sentido, las películas de José Neches son un claro ejemplo, como veremos a través del análisis de un ramillete de ellas ${ }^{35}$, de la complejidad para descifrar, inmersas en un lenguaje soterrado, difuso y ambiguo, las luchas y las aspiraciones de la mujer en una sociedad eminentemente patriarcal; unas películas cuyo estudio posibilita interesarnos, no solo por la opresión histórica sufrida por ellas, sino también por la fuerza, individual y colectiva que emana de estas mujeres ${ }^{36}$.

La Laguna (Tenerife): CAL, Cuadernos Artesanos de La Latina, XX; Melendo, A. (2017). La construcción plástica de la imagen femenina en las películas del marqués de Villa Alcázar. De 1943 a 1945. Arenal: Revista de Historia de las Mujeres, 24 (2), 477-508; Ortega Arjonilla, E. (Ed.) (2017). "Reconstrucción de la memoria histórica a propósito de la mujer en la obra del marqués de Villa Alcázar. De cultura visual y documentales en España (1934-1966): la obra cinematográfica del marqués de Villa Alcázar. Granada: Editorial Comares, $127-$ 166.

33 Nash, M. (1989). "Invisibilidad y presencia de la mujer en la historia", 103-104. Obtenido de: http: //www. estudioshistoricos.inah.gob.mx/revistaHistorias/wp-content/uploads/historias_10_101-120.pdf [Consulta: 5 de septiembre de 2017].

34 Ibidem. 108.

35 Las películas a las que atendemos son elegidas en base a la claridad que ofrecen con respecto al tema que trabajamos en nuestro estudio. En el mismo no pretendemos realizar un estudio estadístico de cuándo, en qué fragmentos aparecen las mujeres o la frecuencia con la que realizan su aparición. Las películas se eligen en base a la significación que emanan de ellas en torno al objeto de estudio.

36 La profesora Nash plantea cómo existe un cambio de paradigma en las metodologías que abordan los estudios de la mujer en autores como H. Smit y su ensayo "Feminist and de metodology of Women's History" al alejarse de los estudios que victimizan a las mujeres para centrarse en los logros que, a través de diversos modos, han ido consiguiendo a lo largo de la historia. Recogido en: Nash, M. (1989), op. cit. 103. 
Para explicar el concepto de invisibilidad en la obra cinematográfica de este cineasta, necesitamos detenernos en el análisis de la primera película realizada por Neches: Cortijo andaluz (1945). La cinta trata de evidenciar cómo era la vida de aquellos que habitan ese microcosmos social que se genera en torno a tan emblemático lugar. Este cortometraje se divide en dos partes bien diferenciadas: en la primera de ellas, el Cortijo de San Cayetano se convierte en escenario de una mirada cinematográfica que, acompañada por los brillantes sonidos de una guitarra flamenca, un piano y la voz de un cantaor, introduce al espectador, conducido por el discurso de carácter lírico del narrador, en la belleza de unas imágenes que desprenden poesía por sí solas. Una sucesión de planos, engarzados por el montaje, presentan al cortijo como un lugar de serenidad y trabajo a la vez que resalta los lugares más representativos del mismo, tales como el jardín, que ayuda a alimentar el espíritu a través de las fragancias que de él emanan, o la capilla, espacio en el que, según la voz over, "van las miradas en señal del perdón y buscando la protección divina". Así mismo, se da cuenta de la vivienda señorial y del patio, con un arriate que el narrador describe cargado de flores, y que "pregona la sensibilidad femenina".

En la segunda parte del film, la arquitectura deja paso a la figura humana: mozos, guardas, batidores, manijeros o jayanes, que "comienzan los preparativos para la gran batalla (...) Los cavadores, azadas, rastrillos, van saliendo [asegura el narrador] mientras el manijero recibe orden del aperador. Sale la caballería y del largo establo la boyada que, pesada y tozuda forcejeará para vencer el cuajo de la tierra". Entonces, un corte de montaje da paso a un plano en el que, una joven y bella mujer, situada en aquel arriate que pregonaba la sensibilidad femenina (Fig. 1), despide al capataz quien, montado en su enérgico caballo, atraviesa el espacio de lo doméstico para adentrarse en el ámbito de lo agreste y del esfuerzo, emparentado en el film, como hemos podido comprobar, con lo masculino (Fig. 2). La fuerza de los hombres, las bestias y hasta la de los tractores, contrastan, por tanto, con las delicadas muchachas que, felices, riegan el jardín y recogen flores para llevárselas a las señoritas, "no sin antes, asegura la voz off, colocarse en el pelo las más rojas" (Fig. 3).
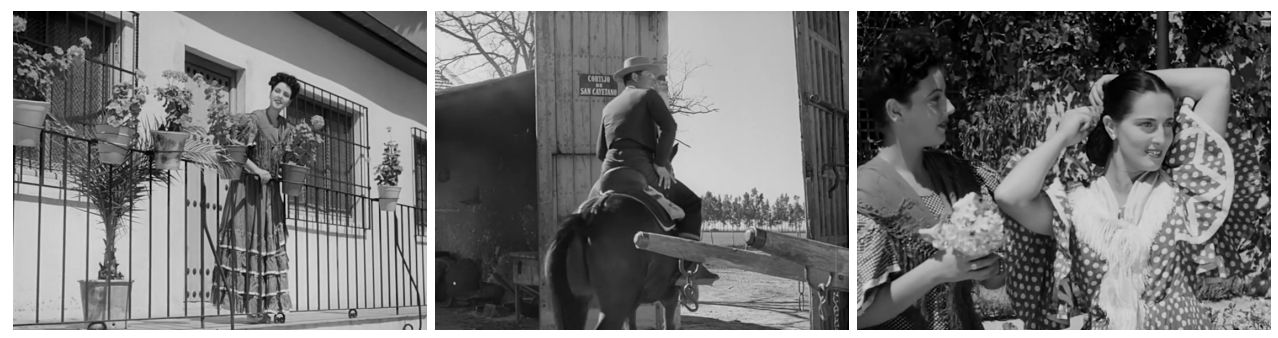

Fig. 1. Cortijo andaluz: despedida de muchacha en el balcón

Fig. 2. Cortijo andaluz: despedida del joven a caballo

Fig. 3. Cortijo andaluz: jóvenes adornándose el pelo

Unas pocas labores más aparecen asociadas a lo femenino, a saber, la educación de los niños que habitan el cortijo, la alimentación de las gallinas a base de pan que una mujer madura esparce entre los animales, y la preparación de un caldero que espera a su víctima y que acompañará a la fiesta de fin de semana que se realiza en torno a la consagración del trabajo. 
Nos encontramos así, por una parte, con una distinción clara entre géneros en relación al trabajo, que no es más que el reflejo de la sociedad en la que se realiza el film, y por otra, con la invisibilidad de la mujer en relación a sus ocupaciones en el ámbito rural, que lejos de detenerse en los cuidados del jardín, tal y como aparece en la cinta, abarca, realmente, la faena productiva fuera del hogar y la labor social, asumiendo la responsabilidad de la unidad y la atención familiar. En este sentido, resulta cuanto menos significativa, la aportación que, a raíz de la presentación de esta película en la XV Muestra de Cine Rural de Dos Torres (2017), realizara una señora del público, coetánea al año de realización del film, explicando que, bajo esas bellas imágenes, se echaba de menos el esfuerzo y la lucha diaria de unas mujeres que trabajaban de igual modo en el ámbito doméstico y en todas aquellas actividades que el campo requería fuera del cortijo y de su propio hogar.

En Reses bravas (1945), el segundo de los documentales realizados por Neches, encontramos, de nuevo, ese sentido lírico que emitía la cinta analizada con anterioridad. La belleza de las imágenes, el flamenco y el discurso poético del narrador introducen al espectador en un mundo, el del toro, en el que, a pesar de su temprana presencia en él y salvo en contadas ocasiones, la mujer siempre ha desarrollado una labor marginal. Es fácil encontrarlas en los tendidos como objetos decorativos que iluminan con su belleza tan ancestral espectáculo; y hasta podemos imaginarlas como sufridoras, reclinadas rezando y esperando una llamada que apacigüe el desasosiego de la madre o esposa del matador, pero siempre desempeñando una labor pasiva, por mucho que a comienzos del siglo XVII, algunas de ellas, comiencen a torear a caballo en fincas y fiestas privadas ${ }^{37}$. Por eso, en esta segunda película, el cineasta zamorano excluye, definitivamente, del film a la mujer. Las imágenes, de notable belleza, muestran la extraordinaria nobleza y elegancia de unos animales conducidos por unos hombres que exhiben su valor cabalgando entre las reses bravas. Rejoneadores y herraderos exponen su fuerza y su inteligencia, así se pone de manifestó cuando el narrador explica que, "el herradero reconoce como norma que más vale maña que fuerza", mientras los ganaderos observan el varonil espectáculo.

\subsection{Las películas de José Neches en el SEA}

En la primera película que José Neches realiza desde el SEA se produce algo similar. Efectivamente, en Concurso nacional de tractoristas (1959), los toros son sustituidos por tractores que dinamizan la composición de las imágenes a través de sus brillantes colores ${ }^{38}$, y el discurso de carácter lírico del narrador es sustituido aquí por la presencia de Matías Prats quien, no solo cuenta lo que sucede al más puro estilo de los documentales de NO-DO, con un tono marcadamente periodístico, sino que, también, aparece en escena ${ }^{39}$. Hemos de decir al respecto que la película pretende dar

37 Precisamente por la rareza y el valor que muestra Nicolasa Escamilla, conocida como "la Pajuela", al tirarse al ruedo en una de las corridas más importantes de la época, Goya decide inmortalizarla en tan atrevida acción. Y aunque en el siglo XIX se reconoce su entrega y valor en el mundo del toro, Juan de la Cierva, ministro de Antonio Maura, prohibió por real decreto el toreo de la mujer a pie, pues según la opinión pública de la época era impropio para la Fiesta.

38 La película muestra los avances tecnológicos en este sentido y abandona el blanco y negro de las anteriores cintas para explorar el mundo del color.

39 Se trata, por tanto, de un narrador homodiegético de focalización interna que participa activamente en la acción, algo que no era habitual en los documentales de NO-DO, por mucho que el formato con el que se desarrolla este documental sea deudor de aquellos. 
cuenta de la transformación económica por la que atraviesa el país en este período conocido como desarrollista, una etapa en la que los empresarios inician un proceso de mecanización en el que la presencia de la mujer, al menos en determinados espacios públicos, es nula, puesto que, como se aprecia en las imágenes, no participa en ninguna de las actividades que se dan cita en el concurso, ni siquiera podemos verla entre un público, apasionado y masculino, que empatiza con la destreza y la fuerza de los jóvenes concursantes. Es evidente, de nuevo, que la invisibilidad de ellas en estas secuencias, a pesar de que han transcurrido catorce años con respecto a las películas analizadas con anterioridad, responde a la realidad social en la que se realiza dicho documental, una realidad en la que ya se han asumido plenamente los valores patriarcales impuestos por el Nuevo Régimen.

En este sentido conviene que nos detengamos ahora en uno de los films en los que, desde el punto de vista plástico, se comienzan a vislumbrar algunos de los elementos estéticos que caracterizan el cine documental de Neches, a la vez que nos permite continuar profundizando en el papel que juega la mujer en la cinematografía del autor, nos estamos refiriendo a: El monasterio contesta (1960). El film arranca con unos planos en los que la arquitectura se convierte en la única protagonista. La enigmática cabecera de este documental, junto con los demás títulos de crédito, se impresiona sobre la imagen del Monasterio de la Santa Espiga (Valladolid), hasta dejar paso a un plano de corte hitchcockiano en el que los pies de un joven, que porta una maleta, avanzan con rumbo desconocido aún para el espectador. Finalmente podemos observar cómo el hombre atraviesa el arco de medio punto que separa el exterior del interior de este edificio que, sin duda, juega un papel protagónico en el film, así lo denotan las propias palabras del joven quien, más adelante, al compas de la cámara, describe la importancia, la antigüedad y la belleza de los muros que han de acogerlo durante algún tiempo. Sin solución de continuidad, la mirada cinematográfica se instala ahora en los aposentos de este narrador-protagonista que, a través de su diario, aclara al espectador que el sentido de su estancia allí se justifica porque es alumno de la Escuela de Capataces Agrarios.

Desde un punto de vista cinematográfico, la película plantea una línea difusa entre la realidad ficcionalizada y la realidad ${ }^{40}$ objetivable propia del documental ${ }^{41} \mathrm{sin}$ ser la primera vez que esto sucede en el cine de Neches, ya que en una cinta coetánea a la que nos ocupa, Ayudaos los unos a los otros (1960), el cineasta realiza un planteamiento similar que repite, como tendremos ocasión de comprobar, en obras posteriores. Sin lugar a dudas, José Neches traslada a la pantalla un relato, que podríamos denominar clásico, sirviéndose de una de las posibilidades formales que ofrecen los llamados géneros del yo, para dejar constancia de lo vivido por un protagonista que elige el cauce de la autobiografía, a través del diario, como manifestación textual para contar la verdad.

40 "Entendemos como realidad, en términos muy generales, un campo referencial que en todo caso abarca el mundo empírico, sensible, habitable, pero que también se dilataría hacia los territorios de lo conceptual, simbólico, sentimental, imaginario, etc., esto es, todo aquello que puede afectar (o verse afectado por) la acción física o mental del hombre en su dimensión tanto individual como social". En: Monterde, J. E. (2001). "Realidad, realismo y documental en el cine español”. En Catalá, J. M., Cerdán, J., y Torreiro, C. (Coords.). Imagen, memoria y fascinación. Notas sobre el documental en España. Madrid, Ocho y Medio: Libros de cine, 15-16.

41 Entendiendo, tal y como explica José Enrique Monterde que, "cabría admitir diversas variantes del cine no ficcional en función del grado de elaboración del producto fílmico”. Ibidem. 19. 
Esta consideración resulta especialmente interesante si se tiene en cuenta que la filmografía de Neches hemos de relacionarla con el género de documental formativo, cuya finalidad última consiste en comunicar y mostrar, mediante un mensaje seductor, los abundantes conocimientos y destrezas, relacionados con el mundo agrícola, utilizando unos métodos basados en la confianza entre el emisor y el receptor. Es decir, se trata de que el mensaje pedagógico, o de cualquier otra índole que pudiera llevar aparejado el film, sea creíble. Se ponen en juego, por tanto, desde el punto de vista teórico, los conceptos de realismo y verosimilitud en el sentido apuntado por el Profesor Pozuelo Ivancos cuando explica cómo "la literatura crea simulacros de realidad, representa acciones humanas y realiza un peculiar isomorfismo de manera que los hechos representados se asemejan a los acaecidos a personajes que se mueven realmente en el escenario de nuestra existencia" ${ }^{\prime 2}$. Pero no resulta menos cierto, como señala $\mathrm{M}^{\mathrm{a}}$ Paz Cepedello que:

Nuestra experiencia como lectores nos enseña que los hechos más fantásticos pueden resultar verosímiles y los más cercanos a la realidad absolutamente increíbles (...) La verosimilitud es el resultado de un proceso más complejo en el que entran en juego rasgos inmanentes y elementos extratextuales que colaboran decididamente en que los relatos proyecten ese efecto de realidad ${ }^{43}$.

Por tanto, si las historias de Neches consiguen que el receptor al que van dirigidas sus obras las interiorice como propias, es porque construyen un discurso basado en técnicas que generan el efecto de realidad perseguido ${ }^{44}$, a través, como dice la Profesora Cepedello, de:

La presencia de nombre propios, lugares y hechos históricos y la manera en que estos elementos se imbrican en el relato como argumentos de autoridad que anclan al receptor literario [cinematográfico en este caso] a una realidad que, además, le resulta próxima en términos cronológicos y, en muchos casos, sentimentales ${ }^{45}$.

Por eso, el cineasta no tiene empacho en combinar una serie de imágenes creadas ex profeso para la configuración del film que nos ocupa, con otras de material encontrado, como la visita del General Franco y su esposa al Monasterio de la Santa Espina, que, mediante estas palabras del narrador: "Un día nos visitó el Jefe del Estado. Aquel día estaba más bonito el monasterio. Gentes de otros lugares vinieron aquí para presenciar el acontecimiento", confieren unidad y credibilidad al discurso cinematográfico nechesiano.

Pero, ¿en qué medida la película arroja luz sobre el tema que aquí nos viene ocupando? Pues bien, en primer lugar, nos encontramos con una circunstancia que nos permite observar y valorar cómo en 1960 la educación y la formación entre hombres

42 Pozuelo Ibáncos (1993). Poética de la ficción. Madrid: Síntesis, 10.

43 Cepedello, $M^{a}$ P. (2017). Los mecanismos de la interpretación: la eficacia de la ficción en la reconstrucción de la memoria a propósito de Los girasoles ciegos, Studia Romanica Posnaniensia, 44(1), 26-27.

44 Ver: Iser, W. (1989). "El proceso de lectura y La realidad de la ficción”. En WARNING, Rainer (Ed.), Estética de la recepción. Madrid: Taurus, 165 y ss.

45 Cepedello, Ma P. (2017). op. cit. 27. 
y mujeres se desarrolla, todavía, bajo el signo de la desigualdad. Basada en la eficacia educativa de consideraciones fascistas, en las que se defiende una enseñanza diferenciada para cada sexo, la película pone de manifiesto cómo, de nuevo, la mujer permanece invisible en este mundo, el de la Escuela de Capataces Agrarios, creada por el Ministerio de Agricultura, en el que ellas no tienen cabida puesto que han de cumplir una misión diferente a la del hombre. La cámara recorre diferentes escenarios, en los que se desarrolla esta formación masculina sin que podamos observar ninguna presencia femenina en ellos excepto en un momento muy preciso del film, aquel en el que nuestro joven protagonista comienza a escribir la historia de su llegada allí. Un plano lo recoge escorado a la izquierda de la composición mientras que la derecha es ocupada por tres fotografías colocadas con anterioridad en la pared de su cuarto (Fig. 4). Mediante un corte de montaje, la mirada cinematográfica muestra la importancia de estas fotos que, ahora, aparecen solas en el encuadre conformando un triángulo en cuyos vértices destacan las mujeres que la película subraya, de este modo, como importantes en la vida del protagonista (Fig. 5), mujeres que, una vez más, sostienen al hombre en los momentos importantes de su vida cumpliendo con esa función reproductora y aglutinadora que forma parte de aquellos idearios franquistas en los que destaca la sensibilidad femenina frente al intelecto masculino.
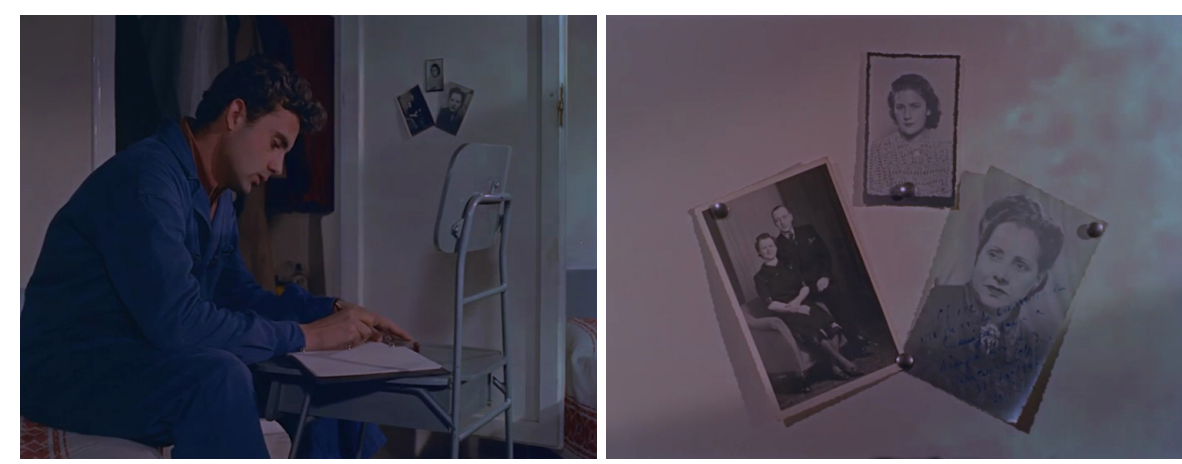

Fig. 4. El monasterio responde: joven escribiendo un diario

Fig. 5. El monasterio responde: fotografías familiares

El estudio de este último film nos sirve de engrase para poder plantear aquí, cómo el concepto de invisibilidad en las películas de Neches va virando hacia otro señalado ya en el título de nuestro trabajo: la diferencia. Y es que, a partir de ahora pretendemos detenernos en aquellos títulos más representativos del cineasta, en los que las mujeres adquieren un protagonismo fundamental, dejando de ser invisibles para existir como diferentes. En este sentido, recurrimos al concepto amplio de cultura femenina señalado por Gerda Lerner en 1975 para atender en lo que sigue:

No solo a las ocupaciones discriminadas, el status, las experiencias y los rituales de la mujer, sino también su conciencia social responsable de la interiorización de los atributos patriarcales. En algunos casos, tal cultura abarcaría las tensiones 
generadas entre los dictados patriarcales institucionalizados y el esfuerzo de las mujeres por conquistar su autonomía y emancipación ${ }^{46}$.

El análisis pormenorizado de la película El Encín, realizada por Neches en 1961, es un buen comienzo, como veremos, para comprender algunos de estos presupuestos teóricos planteados por Lerner.

El Encín es un edificio perteneciente al Instituto Nacional de Investigaciones Agronómicas, destinado a la formación de Agentes y Ayudantes del Servicio de Extensión Agraria. El objetivo del film es mostrar las diferentes enseñanzas que se imparten en la escuela, y el desarrollo de la vida diaria de los alumnos y alumnas que estudian y residen en ella. La presentación del lugar se realiza a partir de un gesto metalingüístico en el que, un proyector de cine, manejado por un instructor que está rodeado de un grupo de alumnas de la escuela, dibuja en la pantalla la imagen de tan singular edificio. A continuación, un corte de montaje deja paso a la imagen real del mismo mientras que la voz de un narrador heterodiegético, que acompaña en todo momento a las imágenes, ubica al espectador. La voz over define con exactitud, como vemos, las características y particularidades de este centro de enseñanza:

(...) Dentro de esta finca está la Escuela de Agentes y Ayudantes del Servicio de Extensión Agraria. En ella completarán sus conocimientos, aumentarán su destreza, y aprenderán a transmitir al agricultor, con un lenguaje llano y sencillo, las enseñanzas que adquieran en este centro. Luego, en sus lugares de destino, en contacto con el agricultor, recordarán y explicarán lo que aquí habían aprendido (...) Comienza uno de los cursos para Ayudantes de Economía Doméstica. Un grupo de estudiantes ha sido seleccionado para asistir a este curso, y en las aulas, recibirán las enseñanzas precisas.

Ciertamente, un plano detalle da cuenta de un cartel publicitario que anuncia el comienzo del $2^{\circ}$ Curso de Ayudantes de Economía Doméstica. Este deja paso a otro, que ofrece al espectador la imagen de un grupo de mujeres ("un grupo de estudiantes seleccionado", según la voz del narrador), uniformadas y aglutinadas en torno a una instructora, que resulta clave para entender que el tipo de aprendizaje que se ofrece en este lugar parte de la diferenciación de géneros como una de las bases instauradas por el Nuevo Régimen en materia de enseñanza. Hemos de tener en cuenta, que la primera promoción de Ayudantes de Economía Doméstica empieza a actuar en $1960^{47}$ con la finalidad de completar la labor de ayuda al agricultor que el SEA encomienda a un sector de la población masculina constituido por los Agentes de Extensión Agraria. El servicio de Ayudantes de Economía Domestica, entonces, nace con el fin de ayudar a la mujer campesina a mejorar su hogar. Esta necesidad se recoge dos años antes en el Boletín Informativo del Servicio de Extensión Agraria haciendo hincapié en la diferenciación de la enseñanza según el sexo, como se puede leer en lo que sigue:

\footnotetext{
$46 \quad$ Nash, M. (1989). op. cit. 10.

47 Los Agentes de Extensión Agraria eran todos hombres porque, aunque en la convocatoria de 1955 no se excluía explícitamente a las mujeres, el texto exponía como requisito haber cumplido el servicio militar. (BOE, 350, 16/17/1955).
} 
Igualmente, y transcurrida ya la primera etapa de puesta en marcha del Servicio, parece llegado el momento de abordar actividades relacionadas con las juventudes rurales y mujeres campesinas. Y puesto que unas y otras vienen siendo atendidas por dos admirables Organizaciones, creación del actual Régimen, bajo la égida de nuestro Caudillo, el Frente de Juventudes y la Sección Femenina, se ha juzgado muy conveniente establecer contacto con las Organizaciones citadas, para estudiar unas normas de estrecha colaboración con ambas, por cuyo conducto los jóvenes rurales de uno y otro sexo y las madres de familia de los hogares campesinos van a poder recibir nuevas ideas y se les va a iniciar en la práctica de las mismas ${ }^{48}$.

Habría que recordar, por tanto, que antes de obtener el título de Ayudante de Economía Doméstica estas mujeres deben formarse como Instructoras Rurales mediante un curso, de dos años de duración, que se imparte en la Escuela de Orientación Rural Onésimo Redondo, de la Sección Femenina. Después de la obtención de este título se requiere un año de prácticas en las cátedras ambulantes, pertenecientes también a la Sección Femenina, tras el cual pueden optar, finalmente, a la plaza de Ayudantes de Economía Doméstica del Servicio de Extensión Agraria.

En la película que nos ocupa llama la atención, desde el punto de vista estilístico, el marcado carácter documentalista de las imágenes y la sustitución de aquel lenguaje lírico del narrador, que caracteriza a otras películas de Neches, por un discurso directo, desprovisto de toda floritura, que contribuye a mantener y encauzar la atención del espectador. Así, la voz off, introduce al observador en los distintos cursos a los que diariamente asisten las futuras Ayudantes de Economía Domésticas, destacando algunas áreas de conocimiento, elementales para el desarrollo de su trabajo, como: la puericultura, los cursos de cocina, trabajos manuales y confección de útiles para el hogar o el manejo de la multicopista (Fig. 6). Alba Díaz-Geada observa que, "atendiendo a las materias impartidas en los dos estadios formativos, en la formación específica como agentes del SEA ganan peso los elementos metodológicos, en coherencia con la importancia de este aspecto para el servicio" "49. Así mismo, el deporte se presenta como una actividad destacada en este proceso de formación, heredera de algunos de los principios promulgados desde el seno de la Sección Femenina, por los que el cuerpo de la mujer debía de mantenerse sano y fuerte para el feliz cumplimiento de su función reproductora.

Pero, esta diferenciación de géneros se ve más reforzada, si cabe, en el momento en que aparecen en escena los alumnos que realizarán el $4^{a}$ Curso de Agentes de Extensión Agraria. Las actividades destinadas a la población femenina se contraponen a las desempeñadas por el sector masculino, entre las que destacan: el manejo de instrumentos contra las plagas, la regulación de máquinas sembradoras y hasta el uso del proyector y la cámara fotográfica como medios de enseñanza en el ámbito rural, pero también como herramientas para consolidar algunos de los conceptos básicos que los jóvenes han de memorizar antes de enfrentarse a una prueba final que les garantice el título esperado (Fig. 7); hasta podemos apreciar una diferenciación clara en las actividades que realizan

48 El SEA y las mujeres y juventudes campesinas, Boletín Informativo del Servicio de Extensión Agrícola, Ministerio de Agricultura, mayo de 1958, 1-2.

49 Díaz-Geada, A. (2015). Modernizar en femenino. Algunas notas sobre el trabajo de las Agentes de Economía Doméstica y los cambios socioeconómicos y culturares en el rural gallego del tardofranquismo. Historia Actual Onnline, 36 (1), 153. Obtenido de: https: //dialnet.unirioja.es/descarga/articulo/5099662.pdf. Consulta: [29 de septiembre de 2017]. 
en su tiempo libre, pues, mientras que ellas se reúnen para recrearse con la televisión o con la finalidad de cantar canciones que les recuerdan a su tierra y a sus seres queridos (Fig. 8), ellos disfrutan de su descanso ejercitando la mente con juegos como el ajedrez considerado, no solo como un deporte, sino como una ciencia cuyas competencias se basan en lo mental, lo físico, lo emocional y lo psicológico (Fig. 9).
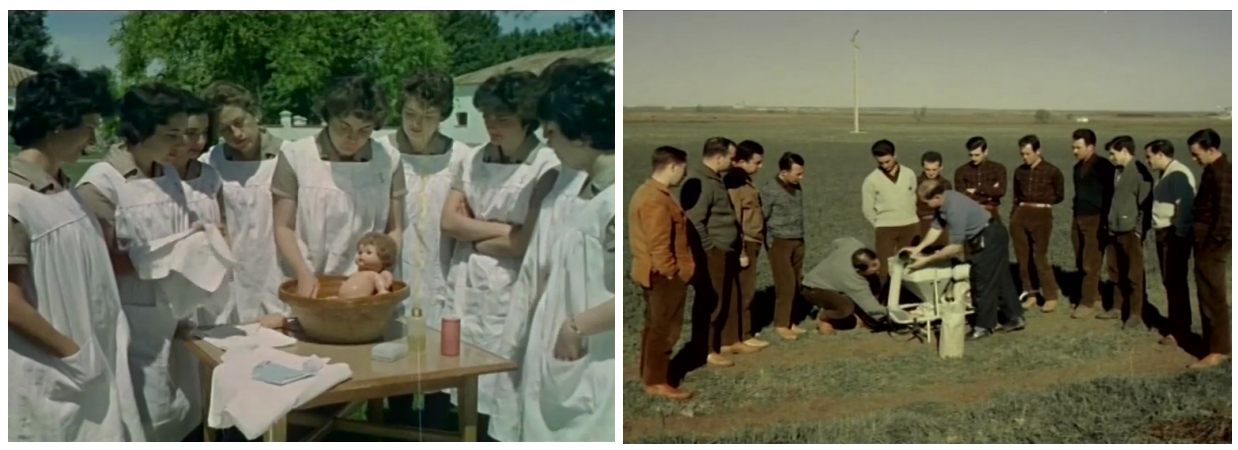

Fig. 6. El Encín: alumnas del SEA en el curso de puericultura

Fig. 7. El Encín: alumnos del SEA aprendiendo el manejo de maquinaria agrícola
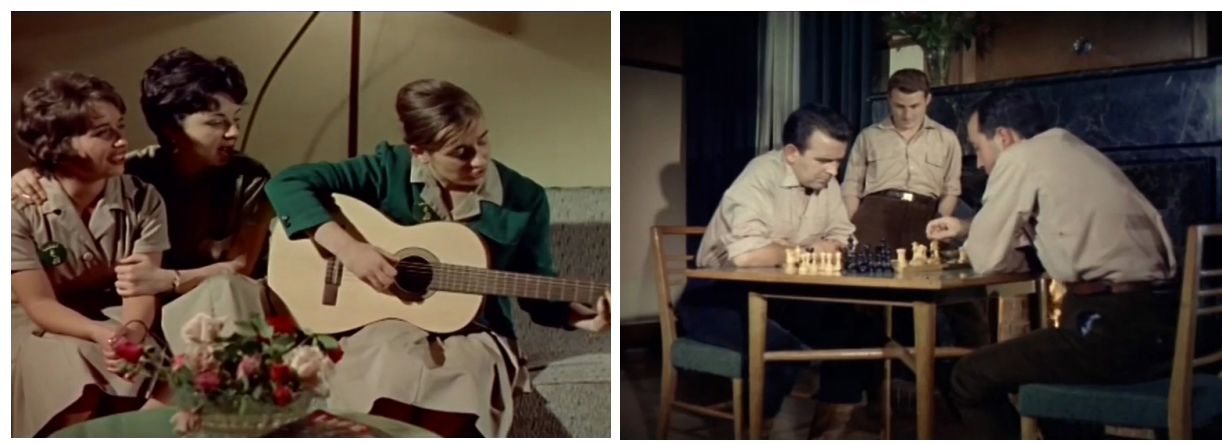

Fig. 8. El Encín: chicas cantando canciones populares

Fig. 9. El Encín: jóvenes jugando al ajedrez en su tiempo libre

Nos encontramos pues en esta película con una mujer visible, que ha dejado de funcionar como prótesis para convertirse en protagonista de unas imágenes que destacan, en el sentido que venimos indicando, por su marcado carácter diferenciador. Algo, por otra parte, que ellas asumen con normalidad debido, como decía Lerner, a esa interiorización de los atributos patriarcales. Algunas publicaciones de la época vienen a ratificar lo propuesto en el film. Entre ellas cabe destacar el número doce de la Revista de Extensión Agraria, publicado en 1962, cuyo título, "Extensión agraria orienta a la mujer sobre: puericultura, decoración, conservas labores y cocina", resume con precisión las ocupaciones del sector femenino en el SEA (Fig. 10) ${ }^{50}$.

50 Entre los contenidos que figuran en el índice de la revista cabe destacar: La mujer en el campo; el trabajo de economía doméstica; la escuela "Onésimo Redondo" de Aranjuez; cómo se prepara a las Ayudantes de Economía Doméstica; recomendaciones de la O.C.D.E. sobre economía doméstica. 


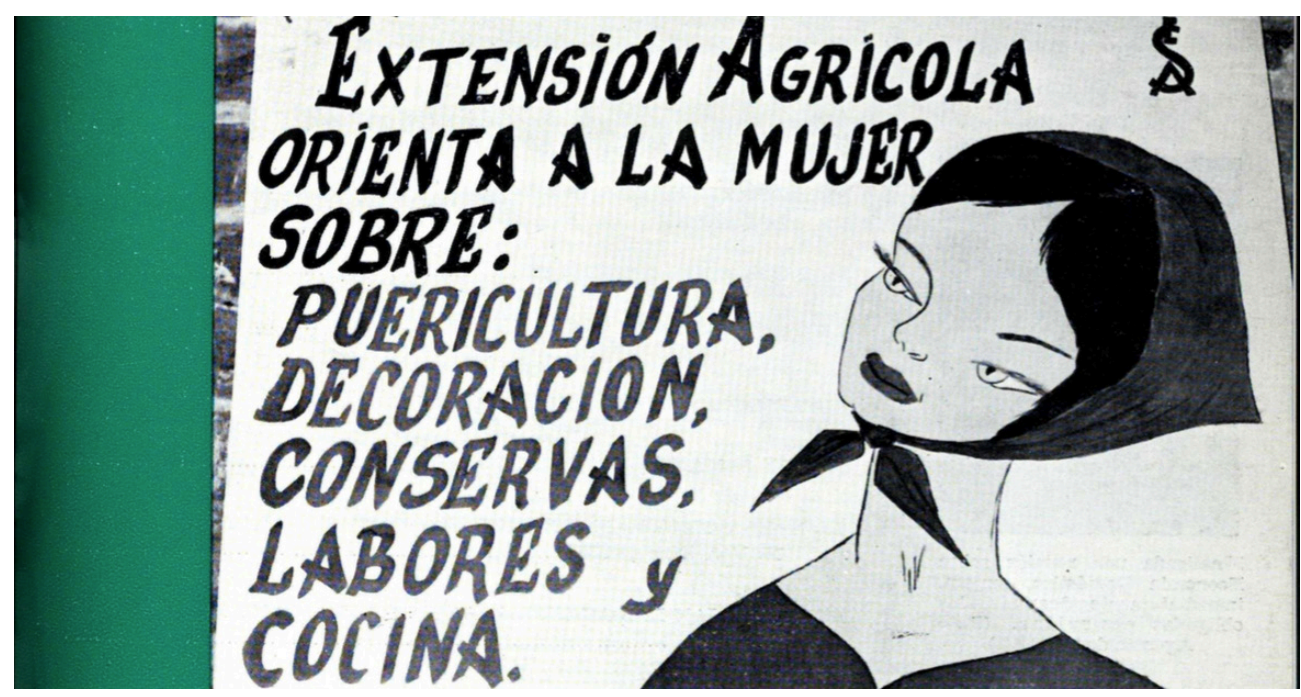

Fig. 10. Revista de Extensión Agraria: ocupaciones de las Agentes de Extensión Agraria del SEA

En 1965 Neches realiza otro documental, Las horas de la tierra, que nos permite aproximarnos, con mayor claridad aún, al sector femenino y sus funciones en el interior del SEA. La película quiere contar, de nuevo en clave poética, la labor que realizan los Agentes de Extensión Agraria y las Agentes de Economía Doméstica durante las cuatro estaciones del año. La imagen de un reloj en la penumbra de un espacio irreconocible, sobre el que se impresionan los títulos de crédito, y el sonido sordo de las campanadas que marcan las doce, introducen al espectador en este film en el que Neches se asegura de que su cámara cinematográfica funcione como algo más que un vehículo para registrar la realidad. Ese trabajo con la forma fílmica se pone de manifiesto en numerosos momentos del film ${ }^{51}$. Pero, desde la perspectiva que nos viene interesando en este estudio, queremos detenernos en el momento en el que, después de que un Agente de Extensión Agraria llega a una Comarca cualquiera con la finalidad de crear una agencia a través de la cual instruir a los agricultores de la zona en la optimización de sus recursos, la película repara en la llegada de la Agente de Economía Doméstica. Han transcurrido cuatro años desde la realización de El Encín, y cuanto menos llama la atención que, en Las horas de la tierra, se produce un cambio de nomenclatura al referirse a las Ayudantes de Economía Doméstica (así lo denotan las palabras del narrador quien, refiriéndose a la joven, se expresa así: "¡Hombre, mira qué bien! ¡Llegas cuando estamos acabando de instalar la Agencia! Se incorpora a nuestro equipo la Agente de Economía Doméstica") que trata de aminorar las diferencias existentes entre uno y otro Cuerpo. No obstante, en el documental se expresa con claridad la labor desempeñada por unos y otras ocupándose así la joven de atender a las familias de los agricultores y los problemas sociales de las comunidades rurales. En la película puede apreciarse cómo la Agente se implica felizmente en la vida de esta comunidad rural participando incluso de las fiestas de Navidad con los habitantes de los distintos pueblos, instruyendo a las amas

51 El análisis del film en este sentido sería objeto de otro estudio en el que habría que atender a aspectos narratológicos, intertextuales, o de otra índole para detectar muchos de los aspectos que configurarían el sistema estético de la obra nechesiana, pero que analizarlos aquí nos apartaría del tema que nos ocupa. 
de casa en tareas domésticas como la costura o la cocina, y estableciendo reuniones periódicas con las mujeres del lugar (Fig. 11) ${ }^{52}$.

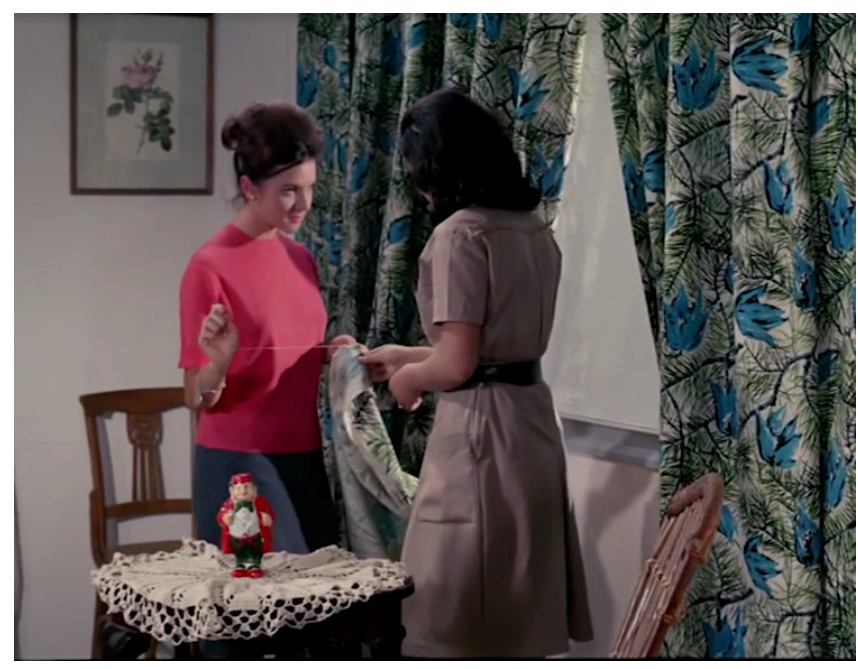

Fig. 11. Las horas de la tierra: Agente de Extensión Agraria instruyendo a un ama de casa de la Comarca

Pero este síntoma de igualdad que viene generado por el cambio de nombre que recibe el Cuerpo de mujeres en el SEA se desvanece cuando un colectivo de 326 funcionarias del Servicio de Extensión Agraria declaran en El País, en 1984, que desde hace quince años intentan poner fin a su discriminación laboral. En el artículo se señala cómo hasta 1965, año en que se realiza la película, recordémoslo, sueldo y módulos fueron idénticos, hasta que la Dirección del Servicio de Extensión Agraria tomó la decisión de aumentar el sueldo a los Agentes de Extensión Agraria sin que se hiciera lo propio con las Agentes de Economía Doméstica, a pesar de ostentar la misma categoría. Pero el distanciamiento definitivo entre ambos Cuerpos, femenino y masculino, parece que se produce en 1972, cuando se convocan oposiciones para Agentes de Extensión Agraria exigiéndoles una titulación superior, mientras que para realizar las pruebas que habilitan a las Agentes de Economía Doméstica continúan admitiendo estudios inferiores a los de grado medio. De esta forma, la discriminación económica se une a la profesional, agravándose la situación cuando a los Agentes se les asigna un coeficiente de 3,6 y en cambio las Agentes obtienen un $2,9^{53}$. Este artículo viene a demostrar que, efectivamente, al menos desde 1969 se tiene constancia, como afirmaba Lerner, de las tensiones que provocan en estas mujeres trabajadoras los imperativos patriarcales ya asentados y el esfuerzo del colectivo femenino por conquistar su autonomía y emancipación desde un trato discriminativo y diferenciador por parte de las distintas instituciones públicas.

52 "Las Agentes del SEA, sin embargo, trabajaban en una misma zona por largos periodos de tiempo, en el marco de una agencia comarcal y de una estrategia de acción conjunta que atendía a las necesidades de las explotaciones agrarias, la juventud y el conjunto de la comunidad". Díaz-Geada, A. (2015). op. cit. 154.

53 Barra, S. (1984). 326 funcionarias del Servi". El Pais, 5 de mayo, Obtenido de: https: //elpais.com/diario/1984/05/05/sociedad/452556011_850215.html. Consulta: [6 de julio de 2017]. 
Por eso no resulta extraño que, todavía, en Flores, el penúltimo de los documentales realizado por Neches en el año 1975, cuando en España se comienzan a respirar los primeros aires de la Democracia, podamos observar aún la inercia de la sociedad española para conservar los viejos clichés marcados por la dictadura en materia de género. El documental privilegia la mirada en los procesos de producción, reproducción, consumo y gestión de las flores en un momento de especial interés por que nuestro país ocupe un lugar visible y destacado en el mercado internacional. Sin embargo, Neches no duda en enmarcar el contenido del film en un prólogo y un epílogo que resultan de especial interés para nuestro estudio. Una voz narradora, esta vez femenina, explica al espectador en la primera parte del film, que hemos denominado prólogo, la transcendencia de las flores en la vida social del ser humano de la siguiente forma:

Las flores tienen, desde luego, un gran sentido en las relaciones humanas, un acto significativo religioso y social (dice mientras aparece la imagen de la boda), ¿cómo no estar presentes las flores? Y las flores, no lo olvidemos, son el preludio de un fruto. La niña en su inocencia aún empieza a sentir atracción por las flores. Un día se siente feliz, es su primer traje largo y blanco, ese día se ve rodeada de flores. Las flores nos acompañarán toda la vida, y por medio de ellas decimos o nos dicen la importancia de los hechos que vivimos. Una flor, un pequeño ramo realza la belleza de la mujer. Las flores nos acompañan siempre.

Mientras, una serie de fotografías encadenadas, que se van sucediendo en la pantalla, atestiguan la importancia de este frágil, bello y simbólico elemento, en acontecimientos como, las bodas, el nacimiento de un hijo, la comunión y hasta la muerte. Como podemos observar, la mujer se convierte aquí en protagonista desde la propia instancia narradora, respondiendo con ello a otro de esos paradigmas por el cual las flores se han asociado, habitualmente, a lo femenino. Además, las palabras pronunciadas por la voz over parecen cobrar un sentido especial porque se ilustran con fotografías como las referidas a una joven que porta un ramo el día de su boda, la de una muchacha que se estrena en la maternidad (Fig. 12), la de una niña que recoge flores del campo, la de otra vestida de comunión o la de una chica que adorna su pelo con una flor con la finalidad de realzar su belleza. Pero es que, más allá de la inocencia que pueda llevar aparejada la idea de vincular la flor a lo femenino, en esta película sobresalen, de nuevo, las marcas de un tejido ideológico, instaurado en la población española, que obedece a la necesidad de diferenciar a los distintos géneros, de entender a la Iglesia como uno de los poderes fácticos de la sociedad del momento, de defender el rol de la mujer como esposa y madre, y de considerar a las jóvenes objetos de deseo cuya lozanía se ve emparentada a la de las propias flores cuando, en el epílogo del film se suceden en la pantalla las mismas fotografía que aparecían en el prólogo (Fig. 13), a la vez que la voz off explica que, "así son las flores: frescas, lozanas, llenas de colorido y alegría, para acompañarle todos los días de su vida igual que le han acompañado en los momentos más importantes de su existencia”. Nos encontramos así con una película que, a pesar de desarrollarse en los albores de la Democracia, plantea una visión continuista de los valores promulgados por el régimen que, una vez muerto el dictador, quieren ser preservados por algunos grupos de poder de la sociedad del española. 

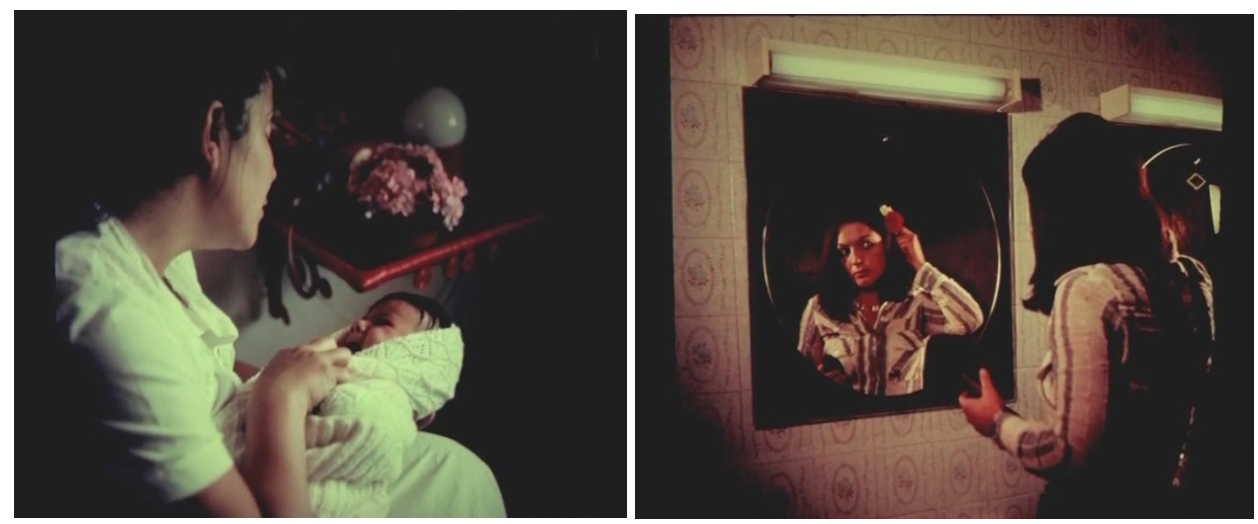

Fig. 12. Flores: el nacimiento de un hijo

Fig.13. Flores: joven con flor en el pelo

\section{A modo de conclusión}

El estudio de la obra de José Neches Nicolás, como factor decisivo en la comprensión del documental rural en España, obliga a incluir en su análisis aspectos relacionados con la política y sociedad del momento. Sobre todo teniendo en cuenta que dichos documentales se realizan a partir de la consideración gubernamental de que la población rural ha de protagonizar el progreso agrario en cooperación con los poderes públicos, y que esta idea pasa por la necesidad de formar, en materia agropecuaria, al campesinado, de ahí la necesidad educativa, como hemos podido comprobar, del SEA, destinada, sobre todo, a los agricultores y sus familias, con una especial atención hacia los jóvenes y las mujeres. Las páginas que anteceden llevan a concluir que los documentales de este cineasta, sujetos a una cierta ideología a la vez que a una importante labor pedagógica, muestran, así se ha demostrado, las marcas de un tejido cultural, político y social que hacen de ellos una herramienta más que aconsejable en las investigaciones para la recuperación de nuestra memoria colectiva en materia de género.

Abordados desde una perspectiva histórica pero también artística, su análisis nos ha permitido constatar cómo, a través de distintos recursos plásticos tales como el uso poético del lenguaje o la ficcionalización de la imagen documental, el cineasta desplaza la atención del espectador hacia otros aspectos que subyacen en cada uno de estos documentales con fines que superan lo estrictamente etnográfico. Efectivamente, se ponen en juego unos artificios ficcionales que contribuyen, paradójicamente, a detectar unos pocos signos de veracidad que nos han conducido a cerciorar que la presencia de la mujer en la filmografía de Neches responde a unos estereotipos sociales que ejemplifican de manera muy certera el papel que desempeña la mujer en la sociedad española, especialmente en el ámbito rural, durante las distintas etapas de la dictadura franquista. Partiendo de un método analítico interdisciplinar, con el estudio de esta obra documental hemos detectado las huellas de un pasado político que, nos ha permitido profundizar en la reconstrucción de la historia del documental en nuestro país. De este modo, hemos profundizado con detalle en los conceptos de 
invisibilidad, en un primer momento, y diferencia, con posterioridad, referidos al género femenino, y nos hemos acercado a la lucha emprendida por las mujeres, llevada a cabo con el único propósito de combatir la discriminación y la desigualdad. No fue fácil desterrar, sobre todo en los núcleos rurales, la permanencia de hogares de tipo tradicional, y una obra documental como la que hemos estudiado aquí permite rastrear los cambios surgidos en la sociedad española durante la dictadura franquista, pero también la perpetuación de algunos comportamientos anquilosados en el pasado cuando se está a punto de entrar en un régimen nuevo como la Democracia. Como se ha podido comprobar en esta obra audiovisual queda un largo camino para que, actitudes progresivamente tolerantes se impongan a los comportamientos del modelo anterior en muchos de los sectores de la población ya que el aprovechamiento de los valores tradicionales de antaño había penetrado con fuerza en el núcleo de la sociedad española. 